\title{
LEVEL OF SPRINT AND JUMP ABILITIES AND INTERMITTENT ENDURANCE OF ELITE YOUNG SOCCER PLAYERS AT DIFFERENT POSITIONS
}

\author{
Pavol Pivovarniček ${ }^{1}$, Martin Pupiš ${ }^{1}, Z_{\text {Zuzana Tonhauserová }}^{1}$, and Martina Tokárová ${ }^{1}$ \\ ${ }^{1}$ Department of Physical Education and Sports, Faculty of Humanities, Matej Bel Univer- \\ sity, Slovak Republic
}

\begin{abstract}
SUMMARY
The aim of the study was to analyse a level of sprint abilities, jump abilities and intermittent endurance of playing groups divided according to playing positions (goalkeepers, defenders, midfielders, forwards) from Slovak national under-21 soccer team ( $N=18$, goalkeepers $n=2$, defenders $n=4$, midfielders $n=7$, forwards $n=5$ ) in time of qualification for the UEFA European Under-21 Football Championship 2011. The level of sprint abilities was diagnosed with the device Fitro Light Gates (FiTRONIC, Bratislava, The Slovak Republic). The criterion for the level assessment was the time obtained in the distance of $10 \mathrm{~m}$ with the exactness of $0.01 \mathrm{~s}$. The level of jump abilities was diagnosed with the device FiTRO Jumper (FiTRONIC, Bratislava, The Slovak Republic). The criterion for the level assessment was the jump height in centimeter $(\mathrm{cm})$ with the exactness of $0.1 \mathrm{~cm}$. Intermittent endurance was diagnosed with Yo-Yo Intermittent recovery test, level 2. The criterion for the evaluation was total overcame distance in the test in metres $(\mathrm{m})$. Differences in the level of sprint abilities, jump abilities and intermittent endurance were recognised and defined with the special subject analysis. The level of sprint abilities of the whole group was presented with the average performance with the value $2.21 \pm 0.08 \mathrm{~s}$, the level of jump abilities with the average performance with the value $39.0 \pm 4.2$ $\mathrm{cm}$ and the level of intermittent endurance with the average value $1283 \pm 294 \mathrm{~m}$, what means $\mathrm{VO}_{2} \max$. $\mathrm{kg}^{-1}=62.7 \pm 4.0 \mathrm{ml} \cdot \mathrm{kg}^{-1} \mathrm{~min}^{-1}$. We have not found out with special subject analysis any significant differences in monitored parameters between groups divided according to playing positions. The significantly lower level was observed only in the level of sprint abilities and intermittent endurance of goalkeepers.
\end{abstract}

Key Words: elite young soccer players, intermittent endurance, jump abilities, sprint abilities.

\section{INTRODUCTION}

The present professional soccer is characterised mainly by dynamics and constant increase in playing speed. We can agree with Nemec, Štefaňák, and Sylvester (2005) that explosive power, speed-power movement abilities and intermittent endurance are limiting movement abilities in soccer. The condition according to Bunc (1999) presents $30-40 \%$ of playing performance. We agree with the statement of Orendurff et al. (2010), Psotta, Bunc, Netscher, Mahrová, and Nováková (2006), Reilly (1997), who say that soccer is intermittent movement activity which contains very short, usually 1 to 5 seconds continuing intervals of endurance with high to maximum intensity, which alternate with intervals of endurance with lower intensity or inaction continuing from 5 to 10 seconds. Little and Williams (2005) include the running acceleration, maximal running speed and agility, which exist usually in the match, into movement activities at high intensity. Bangsbo, Iaia, and Krustrup (2007), Bangsbo, Mohr, and Krustrup (2006), state by players of the highest level 150 to 250 short intensive activities in a match. Hipp (2007) declares that in the soccer match we can observe by player around 100 to 150 sprints with different length. According to findings of Psotta et al. (2006) is 50-65\% of all realized sprints shorter than $5 \mathrm{~m}, 75-85 \%$ of all sprints 
is no longer than $10 \mathrm{~m}$ and the average length of sprints is $9 \mathrm{~m}$ in a single soccer game. Grasgruber and Cacek (2008) state the length of sprints is ca. $15 \mathrm{~m}$ and usually no more than $30 \mathrm{~m}$, every ca. $90 \mathrm{~s}$, it means 0.8 to $1 \mathrm{~km}$ for the whole match. Jovanović, Sporiš, Omrcen, and Fiorentini (2011) declare that number of metres run at high intensity is criteria for division of players in elite or lower performance level. Andrzejewski, Chmura, Pluta, Strzelczyk, and Kasprzak (2012) found out by professional players from European leagues that $90 \%$ of all sprints in matches are till 5 seconds. According to researchers professional players achieve significantly higher speed in first $10 \mathrm{~m}$ of sprints in comparison with players of lower leagues (Grasgruber \& Cacek, 2008; Psotta et al., 2006). Besides Mohr, Krustrup, and Bangsbo (2003) found out by elite players about 28 to $58 \%$ bigger distance $(p<.05)$ in runs at high intensity $\left(>19 \mathrm{kmh}^{-1}\right)$ and sprints compared to players of lower level (run at high intensity $=2.43 \pm .14$ vs. $1.90 \pm .12 \mathrm{~km}$, sprint $=.65 \pm .06$ vs. $.41 \pm .03 \mathrm{~km})$. Haugen, Tønnessen, and Seiler (2012) discovered that Norwegian national soccer players and players of the Norwegian TopLeague achieved higher performance from the point of view of the acceleration and running speed $(p<.05)$ than players of 2 nd division (difference 1.0-1.4\%), $3 \mathrm{rd}-5$ th division (difference 3.0-3.8\%), junior national team (difference 1.7-2.2\%) and junior players (difference 2.8-3.7\%). Considering that this research lasted more years (1995-2010, $n=939$, age $=22.1 \pm 4.3$ years), the authors had the possibility to determine that players in years 2006-2010 were faster about 1-2\% in $20 \mathrm{~m}$ run and had achieved rather maximal speed in comparison with players in years 1995-1999 and 2000-2005.

According to Psotta et al. (2006) the active concept of offensive and defensive phase of the game in playing systems is applied more in present soccer. This concept is characterised by involvement of more players in both phases of the game. It means fast switches of groups of players in transition phases from defence to offense and vice versa, movement activity on the large area of the field, which is evident in spatial intersection of players from particular groups and horizontal and vertical circulations of players in offensive phase. Bangsbo has already found out in the year 1994 that midfielders make the biggest distance in the match; however the distance in runs at high intensity did not vary by players at different playing positions (Bangsbo, 1994). Rebelo et al. (2012) discovered by elite U19 soccer players that the level of intermittent endurance was significantly higher in comparison with players of the same category from the lower league. Krustrup et al. (2006) and Rostgaard,
Iaia, Simonsen, and Bangsbo (2008) found out significantly higher $(p<.05)$ level of intermittent endurance in Yo-Yo test by elite international soccer players compared to elite soccer players from lower league too.

Mentioned studies show the fact that stimulations for development of sprint abilities, jump abilities and intermittent endurance in the training process of soccer players are very necessary. We know that the level of sprint and jump abilities is genetically determined and it depends on neuromuscular coordination and representation of fast muscle fibres but it is necessary to focus on stimulation too.

\section{METHODS}

The observational group consisted of Slovak national under-21 soccer players $(N=18$, goalkeepers $n=2$, defenders $n=4$, midfielders $n=7$, forwards $n=5$ ). The players belonged to the team which had fought for qualification in the UEFA European Under-21 Football Championship 2011 in Denmark in the 7th qualification group together with $\mathrm{U} 21$ national teams from Croatia, Serbia, Norway and Cyprus.

We made this research on October $8^{\text {th }}, 2009$ in the morning, when we as well as Jančoková (2000) can speak about first daily peak of performance. Diagnostics of the level of sprint abilities, jump abilities and intermittent endurance took place in Národnétréningové centrum (NTC) in Senec before qualification match with the national team of Cyprus for European Under-21 Football Championship on October 14th, 2009 in Achna.

Before diagnostics soccer players went through general warm-up (10 minutes) and speed warm-up (10 minutes).

Sprint abilities were measured with the device FiTRO Light Gates (FiTRONIC, Bratislava, The Slovak Republic) in $10 \mathrm{~m}$ run from the middle-standing start at the soccer field with natural grass. Examined soccer player posed a starting position on a start line at the beginning of measurement and started to run with the audio signal „Hop“ which was at the same time a tripper of measuring in the computer device. Within one measurement the soccer players took two trials. We have chosen a better trail to the evaluation.

Jump abilities were measured with the device FiTRO Jumper (FiTRONIC, Bratislava, The Slovak Republic) consisted of a contact switch mat placed on the floor and connected by means of an USB interface to the computer. Jump abilities were diagnosed with vertical jump from a squat with a countermovement and use of swinging arms (Weineck, 2007). Examined players posed on the device position of a 
squat with arms raising forward and gently bent, they made a movement with arms towards rising upward, swished with them and at the same time they made three maximum jumps. Jumping players should make the shortest and strongest take-off, without bending of knees and with relaxed knees. We have chosen the best jump from three jumps for the evaluation.

We have used Yo-Yo Intermittent recovery test, level 2 for diagnostics of intermittent endurance (intermittent Yo-Yo test with short recovery - level 2, Krustrup et al., 2006). Examined players ran sections of $40 \mathrm{~m}(2 \times 20 \mathrm{~m})$. They recovered with relaxed jogging in limited area of $5 \mathrm{~m}$ behind the starting line, only certain period of time, after every section. The running speed and rest intervals were controlled by audible signals recorded on original $\mathrm{CD}$. The test was finished when examined soccer player did not fulfil time limit for $40 \mathrm{~m}$ long section two times consecutively. The result of the test was total exceeded distance given in metres.

In presented study we have used basic statistical descriptive characteristics of performance values: arithmetic average $(M)$, standard deviation $(S D)$, maximum of measured values (Max) and minimum of measured values $(\mathrm{Min})$.

Significance of differences in the level of sprint abilities, jump abilities and intermittent endurance was determined with special subject analysis. The criterion of significance was the value of $1 \mathrm{SD}$. When it came to difference by evaluation of the group of players according to playing positions minimum about one value of SD including the value of SD compared to average performance and the level of the whole group, so we considered it as subject significant difference.

The criterion of the level evaluation of sprint abilities was achieved time in $10 \mathrm{~m}$ distance. In the study we have evaluated the level of sprint abilities in time with exactness of $.01 \mathrm{~s}$.

The criterion of the level evaluation of jump abilities was the jump height in $\mathrm{cm}$ with exactness of $0.1 \mathrm{~cm}$. The device FiTRO Jumper uses for calculation of the jump height relation $h=\left(g \times \mathrm{Tf}^{2}\right) / 8$. The producer FITRONIC s.r.o. guarantees exactness and reliability of the device. There were made certified synchronic measurements with reflexion mat of the company KISTLER.

The criterion of evaluation of intermittent endurance was total exceeded distance in the test in metres and calculated to $\mathrm{VO}_{2} \mathrm{maxkg}^{-1} \mathrm{~V}$ mlkg ${ }^{-1} \mathrm{~min}^{-1}$ with formula $\mathrm{VO}_{2}$ maxkg $^{-1}=$ distance in metres $\mathrm{x} 0.0136$ +45.3 , according to study of Bangsbo, Iaia, and Krustrup (2008).

\section{RESULTS}

The average level of sprint abilities of the whole group was 2.21 $\pm .08 \mathrm{~s}$ (Table 1). Regarding special subject analysis we have discovered significantly lower level only in the group of goalkeepers in comparison with the average performance of the whole group. We have not observed significant differences of other groups divided according to playing positions compared to the average level of the whole group.

\section{TABLE 1}

The level of sprint abilities of players.

\begin{tabular}{lcc}
\hline \multicolumn{1}{c}{ Players } & $\begin{array}{c}\text { Average time } \\
10 \mathrm{~m} \text { run }(\mathrm{s})\end{array}$ & Rank \\
\hline Goalkeepers & $\mathbf{2 . 3 1 \pm . 0 6 \mathrm { s }}$ & 5 \\
\hline Defenders & $2.25 \pm .05 \mathrm{~s}$ & 4 \\
\hline Midfields & $2.18 \pm .10 \mathrm{~s}$ & 1 \\
\hline Forwards & $2.20 \pm .06 \mathrm{~s}$ & 2 \\
\hline Whole group & $2.21 \pm .08 \mathrm{~s}$ & 3 \\
\hline
\end{tabular}

The average level of jump abilities of the whole group was $39.0 \pm 4.2 \mathrm{~cm}$. Regarding special subject analysis we have not discovered significant differences in the average level of the whole group in comparison with the average level of jump abilities of other groups divided according to playing positions (Table 2).

The average level of intermittent endurance of the whole group was $1283 \pm 294 \mathrm{~m}$ ran in the test, what means the value $\mathrm{VO}_{2}$ maxkg- $^{-1}=62.7 \pm 4.0 \mathrm{ml}$. $\mathrm{kg}^{-1} \mathrm{~min}^{-1}$ (Table 3). Regarding special subject analysis we have determined significantly lower level only in the group of goalkeepers in comparison with the average performance of the whole group. We have not observed significant differences of other groups divided according to playing positions compared to the average level of the whole group. 
TABLE 2

The level of jump abilities of players.

\begin{tabular}{lcc}
\hline \multicolumn{1}{c}{ Players } & $\begin{array}{c}\text { Vertical jump with counter- } \\
\text { movement of arms }(\mathrm{cm})\end{array}$ & Rank \\
\hline Goalkeepers & $39.2 \pm 4.0 \mathrm{~cm}$ & 3 \\
\hline Defenders & $39.6 \pm 5.4 \mathrm{~cm}$ & 2 \\
\hline Midfields & $38.0 \pm 3.8 \mathrm{~cm}$ & 5 \\
\hline Forwards & $39.9 \pm 4.8 \mathrm{~cm}$ & 1 \\
\hline Whole group & $39.0 \pm 4.2 \mathrm{~cm}$ & 4 \\
\hline
\end{tabular}

TABLE 3

The level of intermittent endurance of players.

\begin{tabular}{lccc}
\hline \multicolumn{1}{c}{ Players } & $\begin{array}{c}\text { Number of ran } \\
\text { metres in the test }\end{array}$ & Value $\mathrm{VO}_{2}$ maxkg-1 & Rank \\
\hline Goalkeepers & $\mathbf{9 0 0 \pm 8 5 ~ m ~}$ & $57.5 \pm 1.1 \mathrm{ml}^{-\mathrm{kg}^{-1} \mathrm{~min}^{-1}}$ & 5 \\
\hline Defenders & $1345 \pm 126 \mathrm{~m}$ & $63.5 \pm 2.7 \mathrm{ml}_{\mathrm{kg}}{ }^{-1} \mathrm{~min}^{-1}$ & 1 \\
\hline Midfields & $1343 \pm 352 \mathrm{~m}$ & $63.5 \pm 4.8 \mathrm{ml}^{-1} \mathrm{~kg}^{-1} \mathrm{~min}^{-1}$ & 2 \\
\hline Forwards & $1304 \pm 288 \mathrm{~m}$ & $63.0 \pm 3.9 \mathrm{ml}^{-1} \mathrm{~kg}^{-1} \mathrm{~min}^{-1}$ & 3 \\
\hline Whole group & $1283 \pm 294 \mathrm{~m}$ & $62.7 \pm 4.0 \mathrm{ml}^{-1} \mathrm{~kg}^{-1} \mathrm{~min}^{-1}$ & 4 \\
\hline
\end{tabular}

\section{DISCUSSION}

We agree with statements of Reilly, Bangsbo, and Franks (2000) that soccer players do not have to dispose with extraordinary performance in any field of physical performance but they have to have appropriate high level in all fields. The authors Bunc and Psotta (2001) mention that physiological presuppositions and norms represent necessary conditions for success at the professional level.

Sprint abilities, jump abilities and intermittent endurance in soccer belong to limiting movement presuppositions in achievement of top playing performance at the world level. On the one side considering comparison of the level of sprint abilities of individual playing positions, midfielders have achieved the best time $(2.18 \pm .10 \mathrm{~s})$ surprisingly. Sporiš, Jukić, Ostojić, and Milanović (2009) had observed Croatian elite soccer players $(N=270)$ in seasons 2005/2006 and 2006/2007 and discovered that forwards had achieved the highest performance considering sprint abilities in 5, 10 and $20 \mathrm{~m}$. On the other side it is necessary to point out that we have not discovered significant differences in performance levels of players in the field compared to the whole group by comparing all groups divided according to playing positions. Mentioned time of our midfielders was better only about $3.2 \%$ compared to defenders and about . $9 \%$ compared to forwards. We have found out significan- tly lower level of sprint abilities only in the group of goalkeepers $(2.31 \pm .06 \mathrm{~s})$ compared to the whole group. It is important to notice that if we had defined the determination of subject significance with other criterion as was the value of one decisive divergence, so the results would be interpreted differently. Taşkin (2008) came to similar results when he did not discover significant differences ( $p>$.05) among groups of players divided according to playing positions belonging to professional soccer teams $(N=243)$. The matter of his research was running speed in $30 \mathrm{~m}$. Similarly Rampinini et al. (2007) did not determine significant differences ( $p>$.05) among groups of defenders, midfielders, forwards and goalkeepers at professional and non-professional level $(N=78$, age $=21.0 \pm 4.9$ ) considering running speed in $30 \mathrm{~m}$ too.

Malý et al. (2011) discovered that Czech national U16 soccer players $(N=23)$ achieved the level of sprint abilities in time $1.87 \pm .10 \mathrm{~s}$ in $10 \mathrm{~m}$ run on the surface with artificial grass. Cometti, Maffiuletti, Pousson, Chatard, and Maffulli (2001) found out that French first league players $(N=29)$ achieved the average level of sprint abilities in time $1.80 \pm .06 \mathrm{~s}$ in $10 \mathrm{~m}$ run on the surface with natural grass. Dauty, Bryand, and Potirion-Josse (2002) discovered that first league players $(N=20$, age $=23.5 \pm 3.7$ years $)$ from French team FC Nantes reached the average performance in $10 \mathrm{~m}$ run with the value $1.82 \pm .08 \mathrm{~s}$ on the surface with natural grass too. Strudwick, Reilly, and Doran 
(2002) determined that players from English team in Premier League $(N=19$, age $=22.0 \pm 2.0$ years $)$ achieved the average performance in time 1.75 $.08 \mathrm{~s}$. Wisløff, Castagna, Helegerud, Jones, and Hoff (2004) discovered that players from Norwegian elite team Rosenborg FC Trondheim $(N=17$, age $=25.8 \pm 2.9$ years) achieved the level of sprint abilities with the value $1.82 \pm .30 \mathrm{~s}$. Measurement was made in indoor shoes on the wooden floor. In our study we have discovered the level of sprint abilities in $10 \mathrm{~m}$ with time $2.18 \pm .10 \mathrm{~s}$. Determined time is influenced by the fact that players from our group started on audible signal. On the one side the final performance in our test was influenced by reaction speed because it exists in game demands. On the other side it is necessary to mention that majority of stimuli in the game have a visual character. It is necessary to say that the level of running speed is influenced by running technique too.

Considering jump abilities we have not determined significant differences in individual groups divided according to playing positions in comparison with the whole group. We have found out that forwards achieved the highest level $(39.9 \pm 4.8 \mathrm{~cm})$. Sporiš et al. (2009) in correspondence with results from our study discovered that forwards had achieved the highest level of jump abilities from all players in the field. Generally in the study of Ibid the highest level of jump abilities was discovered by goalkeepers. In our study the level of jump abilities of forwards was higher about . $8 \%$ compared to defenders, about $1.6 \%$ compared to goalkeepers and about $4.8 \%$ compared to midfielders. In other studies Lago-Peñas, Lago-Ballesteros, and Rey (2011) found out that young soccer players $(N=321$, age $=15.63 \pm 1.82$ years $)$ achieved the best performances in vertical jumps in the groups of goalkeepers and central defenders. Boone, Vaeyens, Steyaert, Vanden Bossche, and Bourgois (2012) discovered that adult players $(N=289)$ from six teams of Belgian Pro League achieved the average performance (squat jump $=40.7 \pm 4.6 \mathrm{~cm}$ and countermovement jump $=43.1 \pm 4.9 \mathrm{~cm}$ ). Considering division of players into groups according to playing positions goalkeepers and central defenders achieved the highest performance compared to the group of all defenders, midfielders and forwards in correspondence with results of the study of Lago-Peñas et al. (2011). Forwards reached higher performance than midfielders and defenders, what is in correspondence with results of our study. Haugen et al. (2012) found out that Norwegian players including senior and junior national soccer players $(N=939$, age $=22.1 \pm 4.3$ years) in years 1995-2010 had reached significantly lower performance $(p<.05)$ in vertical jumps in the group of midfielders compared to other groups divided according to playing positions. Gil, Ruiz, Irazusta, Gil, and Irazusta (2007) state the highest performance of forwards in all observed parameters of endurance, speed, agility and jump abilities. The authors mention that they did not examine elite young soccer players $(N=241$, age $=17.31 \pm 2.64$ years $)$. Wisløff, Helgerud, and Hoff (1998) discovered that players from elite Norwegian League had achieved significantly higher level of jump abilities in the group of defenders and forwards in comparison with the group of midfielders. Mujika, Santisteban, Impellizzeri, and Castagna (2009) did not determine differences $(p>.05)$ between the height of vertical jumps of elite senior soccer players and elite young soccer players. Gissis et al. (2006) compared performance of young soccer players $(N=54)$ divided into group of young national team of Greece, high-performance young soccer players and recreational soccer players. Considering vertical jumps there were observed differences $(p<.05)$ among national soccer team and other groups. There were not observed differences in evaluation of vertical jumps between high-performance and recreational young soccer players. Kalapotharakos et al. (2006) compared three teams $(N=19$, age $=26 \pm 4$ years, $N=15$, age $=24 \pm 4$ years, $N=20$, age $=23 \pm 3$ years) of Greek Super League from the point of view of several anthropometric andcondition parameters. They found out that tolerance of lactate, isokinetic power of the knee extensors and performance in vertical jumps showed higher values $(p<.05)$ of the team which belonged to three best teams of Super league compared to values of observed teams which were in the middle and among last teams of the league. Wong and Wong (2009) found out that Asian young players $(N=16$, age $=16.2 \pm .6$ years) achieved lower performance in vertical jumps in comparison with European and African players. In other studies Arnason et al. (2004) discovered that jump height of elite Icelandic soccer players was SJ $=37.8 \mathrm{~cm}$ and $\mathrm{CMJ}=39.4 \mathrm{~cm}$. Casajüs (2001) discovered that the jump height of Spanish elite team $(N=15)$ was $\mathrm{SJ}=39 \mathrm{~cm}$ and $\mathrm{CMJ}$ with use of arms $=47.8 \mathrm{~cm}$.

Regarding game demands, high level of jump abilities presents an advantage in personal air duels but in running and total speed performance of a soccer player too, what provethe researches of Wisløff et al. (2004), who accomplished significant correlation of sprint in 10 and $30 \mathrm{~m}$ and vertical jumps of elite international soccer players $(N=17$, age $=25.8 \pm 2.9$ years). 
Intermittent endurance was diagnosed with Yo-Yo Intermittent recovery test, level 2. Bradley et al. (2011) state the correlation $(p<.05)$ between results in this test and ran distance at high intensities $(R=.58)$ and total ran distance $(R=.74)$. By interpretation of determined level of intermittent endurance of young soccer players from our group is necessary to regard the statements from the study of Bangsbo, Iaia, and Krustrup (2008) that performance in Yo-Yo intermittent recovery tests grows with the age of young sportsmen. On the one side regarding comparison of the level of intermittent endurance of individual playing positions defenders have achieved the highest performance $(1345 \pm 126 \mathrm{~m})$. On the other side it is necessary to say that we have not determined significant differences at comparison of the groups divided according playing positions compared to players in the field and the whole group. Mentioned level of intermittent endurance of our defenders was higher only about . $2 \%$ and forwards about $3.1 \%$ in comparison with midfielders. We have discovered significantly lower level of sprint abilities of goalkeepers with the value $900 \pm 85 \mathrm{~m}$ in Yo-Yo test compared to the level of the whole group.

In our study all groups of players had adequate value in comparison with recommendations of Weineck (2007). He specifies the average value $1059 \mathrm{~m}$ for professional players at international level. Bangsbo et al. (2008) specify the value $1260 \mathrm{~m}$ for the highest level of players, what responds to average levels of players at all positions with exception of goalkeepers. According to findings of Bunc (1999), the results of the whole group are satisfactory. He states $\mathrm{VO}_{2}$ maxkg- $^{-1}$ of players at world level above the value $60 \mathrm{mlkg}^{-1} \mathrm{~min}^{-1}$, whereby the average value of our group was $62.7 \pm 4.0 \mathrm{mlkg}^{-1} \mathrm{~min}^{-1}$ including goalkeepers.

It is also necessary to mention the limits of carried research. The matter of study was sprint abilities running speed in $10 \mathrm{~m}$ and non specific test of jump abilities. Performance in direct sprint and vertical jump in conditions isolated from real game are only certain preconditions because playing performance of a soccer player is influenced by variability of specific game conditions and actual game demands. The specific movement ability becomes evident with changes of frequency, changes in length of step and also changes in running direction because the player is forced to regulate constantly his direct movement on the ground of perception of external conditions. It is cooperation with teammates for example, perception of opponents and realising of running sprint with a ball. As well as by realizing of shooting the player is forced to adjust the sprint te- chnique before shooting. All these reasons can be necessary for creating of specific field tests in the future which will be valid for sprint and jump abilities and will compare with the tests we present in this study. The unrepeated testing is certain limitation too and it is joined with limitation in reliability. The unrepeated measurement can be influenced by external conditions but also by actual internal disposals of examined individual. However we had to adapt to time limiting and organizing possibilities of the schedule of a national U21 soccer team.

In spite of mentioned limits the study can be an inspiration for condition and athletic coaches of football teams in order to reveal and eliminate weak aspects of their young players, especially in condition trainings in preparatory seasons and individual trainings according to actual results of diagnostics during entire annual training cycle. Given data can serve as the certain norm or standard of elite young soccer players from the point of view of the level of examined movement abilities. The results of study can be a valuable material for scientists, but for coaches, experts and persons interested in soccer too.

\section{CONCLUSION}

The average level of sprint abilities of the players of Slovak national under-21 soccer team was $2.21 \pm .08$ s. The special subject analysis has showed that there were not significant differences by comparison of the level of sprint abilities in the groups of players in the field. The highest level of sprint abilities was discovered in the group of midfielders with the value $2.18 \pm .10 \mathrm{~s}$, then in the group of forwards with the value $2.20 \pm .06 \mathrm{~s}$, and defenders with the value $2.25 \pm .05$ s. The group of goalkeepers has achieved significantly lower level of sprint abilities with the value 2.31 \pm .06 s.

The average level of jump abilities of players of the whole group was indicated with the value $39.0 \pm 4.2$ $\mathrm{cm}$. We have not found out any differences among groups of players divided according to playing positions considering the special subject analysis. The highest level of jump abilities was discovered in the group of forwards with the value $39.9 \pm 4.8 \mathrm{~cm}$, then in the group of defenders with the value $39.6 \pm 5.4$ $\mathrm{cm}$, goalkeepers with the value $39.2 \pm 4.0 \mathrm{~cm}$, and midfielders $38.0 \pm 3.8 \mathrm{~cm}$.

The average level of intermittent endurance of players of the whole group was indicated with the value $1283 \pm 294 \mathrm{~m}$, what means the value $\mathrm{VO}_{2}$ maxkg $^{-1}$ $=62.7 \pm 4.0 \mathrm{mlkg}^{-1} \mathrm{~min}^{-1}$. There were not determined significant differences in comparison of the level of intermittent endurance in the groups of players in 
the field from the point of view of special subject analysis. The highest level of intermittent endurance was noticed at defenders with the value $1345 \pm 126 \mathrm{~m}$ ran in Yo-Yo test, what means $\mathrm{VO}_{2}$ maxkg $^{-1}=63.5 \pm 2.7$ $\mathrm{mlkg}^{-1} \mathrm{~min}^{-1}$, then at midfielders $1343 \pm 352 \mathrm{~m}$, what is $\mathrm{VO}_{2}$ maxkg $^{-1}=63.5 \pm 4.8 \mathrm{mlkg}^{-1} \mathrm{~min}^{-1}$. Then followed the group of forwards with the value $\mathrm{VO}_{2}$ maxkg $^{-1}=$ $63.0 \pm 3.9 \mathrm{mlkg}^{-1} \mathrm{~min}^{-1}$. The significantly lower level of intermittent endurance was discovered only in the group of goalkeepers with the value $900 \pm 85 \mathrm{~m}$, what is $\mathrm{VO}_{2}$ maxkg $^{-1}=57.5 \pm 1.1 \mathrm{mlkg}^{-1} \mathrm{~min}^{-1}$.

\section{REFERENCES}

Andrzejewski, M., Chmura, J., Pluta, B., Strzelczyk, R, \& Kasprzak, A. (in press). Analysis od sprinting activities of professional soccer players. Journal of Strength and Conditioning research.

Arnason, A. Siqurdsson, S. B., Gudmundsson, A., Holme, I., Engebretsen, L., \& Bahr, R. (2004). Physical Fitness, Injuries, and Team Performance in Soccer. Medicine and Science in Sports and Exercise, 36(2), 278-285. doi:10.1249/01.MSS.0000113478.92945.CA; PMid: 14767251

Bangsbo, J. (1994). The physiology of soccer--with special reference to intense intermittent exercise. Acta physiologica Scandinavica, Supplementum, 619, 1-155.

Bangsbo, J., Iaia, F. M., \& Krustrup, P. (2007). Metabolic response and fatigue in soccer. International journal of sports physiology and performance, 2(2), 111-127.

Bangsbo, J., Iaia, F. M., \& Krustrup, P. (2008).The Yo-Yo intermittent recovery test : a useful tool for evaluation of physical performance in intermittent sports. Sports medicine, 38(1), 37-51. doi: 10.2165/00007256-200838010-00004; PMid: 18081366

Bangsbo, J., Mohr, M., \& Krustrup, P. (2006). Physical and metabolic demands of training and match-play in the elite football player. Journal of sport sciences, 24(7), 665-674. doi: 10.1080/02640410500482529; PMid: 16766496

Boone, J., Vaeyens, R., Steyaert, A., Vanden Bossche, L., \& Bourgois, J. (2012).Physical fitness of elite Belgian soccerplayers by player position. Journal of Strength and Conditioning research, 26, 2051-2057. doi: 10.1519/ JSC.0b013e318239f84f; PMid: 21986697

Bunc, V. (1999). Role kondice v př́pravěhráče fotbalu [Fitness role in pratice of football players]. Fotbal a trénink, 5, 20-21.
Bunc, V., \& Psotta, R. (2001). Physiological profile of very young soccer players. The Journal of Sports Medicine and Physical Fitness, 41(3), 337341. PMid: 11533564

Casajüs, J. A. (2001). Seasonal variation in fitness variables in professional soccer players. Journal of Sports Medicine and Physical Fitness, 41(4), 463469. PMid: 11687765

Cometti, G., Maffiuletti, N. A., Pousson, M., Chatard, J.-C., \& Maffulli, N. (2001). Isokinetic strength and anaerobic power of elite, subelite and amateur French soccer players. International Journal of Sports Medicine, 22, 45-51. doi: 10.1055/s-2001-11331; PMid: 11258641

Dauty, M., Bryand, F., \& Potiron-Josse. M. (2002). Relation entre la force isocinétique, le sautet le sprint chez le footballeur de haut niveau. Science and Sports, 17(3), 122-127. doi: 10.1016/S07651597(02)00137-5

Gil, S., Ruiz, F., Irazusta, A., Gil, J., \& Irazusta, J. (2007). Selection of young soccer players in terms of anthropometric and physiological factors. Journal of sports medicine and physical fitness, 47, 25-32. PMid: 17369794

Gissis, I., Papadopoulos, C., Kalapothrakos, V. I., Sotiropoulos, A., Komsis, G., \& Manolopoulos, E. (2006). Strength and speed characteristics of elite, subelite, and recreational young soccer players. Research in Sports Medicine, 14, 205-214. doi: 10.1080/15438620600854769; PMid: 16967772

Grasgruber, P., \& Cacek, J. (2008). Sportornigeny [Sports Genes]. Brno, CZ: FSS MU.

Haugen, T. A., Tønnessen, E., \& Seiler, S. (in press). Anaerobic Performance Testing of Professional Soccer Players 1995-2010. Internalitonal journal of sports physiology and performance.

Hipp, M. (2007). Futbal: Rozvojyy braných pohybovýchschopností, diagnostika a strečing v dru官tve vrcholového futbalu [Football: Development of selected motor skills, diagnosis and stretching of team of senior football]. Bratislava, SK: SPN.

Janačková, L. (2000). Biorytmy v športe (S úvodom do chronobiológie) [Biorhythms in sport (With an introduction to chronobiology)]. Banská Bystrica, SK: FHV UMB.

Jovanović, M., Sporišs, G., Omrcen, D., \& Fiorentini, F. (2011). Effects of speed, agility, quickness training method on power performance in elite soccer players. Journal of Strength and Conditioning Research, 25, 1285-1292. doi: 10.1519/JSC.0b013e3181d67c65; PMid: 21522073 
Kalapotharakos, V. I., Strimpakos, N., Vithoulka, I., Karvounidis, C., Diamantopoulos, K., \& Kapreli, E. (2006). Physiological characteristics of elite professional soccer teams of different ranking. The Journal of sports medicine and physical fitness, 46, 515-519. PMid: 17119514

Krustrup, P., Mohr, M., Nybo, L., Jensen, J. M., Nielsen, J. J., \& Bangsbo, J. (2006). The Yo-Yo IR2 test: physiological response, reliability, and application to elite soccer. Medicine and science in sport and exercise, 38, 1666-1673. doi: 10.1249/01. mss.0000227538.20799.08; PMid: 16960529

Lago-Penas, C., Lago-Ballesteros, J., \& Rey, E. (2011). Differences in performance indicators between winning and losing teams in the UEFA champions league. Journal of Human Kinetics, 27, 137-148. doi: 10.2478/v10078-011-0011-3

Little, T., \& Williams, A. G. (2006).Effects of differential stretching protocols during warmups on high-speed motor capacities in professional soccer players. Journal of Strength and Conditioning Research, 20, 203-207. doi: 10.1519/00124278-200602000-00033; doi: 10.1519/R-16944.1; PMid: 16503682

Malý, T., Zahálka, F., Malá, L., Buzek, M., Hrásky, P., \& Gtyc, T. (2011). Vzt'ahizo kinetickej silydolných končatín $\mathrm{k}$ rýchlostný mindi kátorom bežeckej rýchlosti mladých futbalistov [The relationship of the kinetic force of the lower extremities to which the velocity Mindi an athletic young footballers speed]. Ceská kinantropologie, 15(3), 157-164.

Mohr, M., Krustrup, P., \& Bangsbo, J. (2003). Match performance of high-standard soccer players with special reference to development of fatigue. Journal of sport sciences, 21(7), 519-528. doi: 10.1080/0264041031000071182; PMid: 12848386

Mujika, I., Santisteban, J., Impellizzeri, F. M., \& Castagna, C. (2009). Fitness determinants of success in men's and women's football. Journal of Sports Sciences, 27, 107-114. doi: 10.1080/02640410802428071; PMid: 19058090

Nemec, M., Štefaňák, P., \& Sylvestr, M. (2005). Tréner futbalu [Football coach]. Banská Bystrica, SK: SsFZ TMK.

Orendurff, M. S., Walker, J. D., Jovanović, M., Tulchin, K. L., Levy, M., \& Hoffmann, D. K. (2010). Intensity and duration of intermittent exercise and recovery during a soccer match. $J$ Strength Cond Res., 24, 2683-2692. doi: 10.1519/ JSC.0b013e3181bac463; PMid: 20145552
Psotta, R., Bunc, V., Netscher, J., Mahrová, A., \& Nováková, H. (2006). Fotbal-kondicnitrénink. [Football fitness training]. Praha, CZ: Grada.

Rampinini E, Bishop D, Marcora SM, Ferrari Bravo D, Sassi R, Impellizzeri, FM. (2007). Validity of simple field tests as indicators of match-related physical performance in top-level professional soccer players. Int J Sports Med., 28(3), 228-235. PMid: 17024621

Rebelo, A., Brito, J., Maia, J., Coelho-e-Silva, M. J., Fiquueiredo, A. J., Bangsbo, J. ... Seabra, A. (in press). Anthropometric Characteristics, Physical Fitness and Technical Performance of Under-19 Soccer Players by Competitive Level and Field Position. International journal of sports medicine.

Reilly, T. (1997). Energetics of high-intensity exercise (soccer) with particular reference to fatigue. J Sports Sci., 15(3), 257-263. doi: 10.1080/026404197367263; PMid: 9232551

Reilly, T., Bangsbo, J., \& Franks, A. (2000). Anthropometric and physiological predispositions for elite soccer. Journal of sports sciences, 18(9), 669-683. doi: 10.1080/02640410050120050; PMid: 11043893

Rostgaard, T., Iaia, F. M., Simonsen, D. S., \& Bangsbo, J. (2008). A test to evaluate the physical impact on technical performance in soccer. Journal of Strength and Conditioning research, 22(1), 283-292. doi: 10.1519/ JSC.0b013e31815f302a; PMid: 18296988

Sporis, G., Jukic, I., Ostojic, S. M., \& Milanovic, D. (2009). Fitness profiling in soccer: physical and physiological characteristics of elite players. Journal of Strength and Conditioning Research, 23(7), 1947-1953. doi: 10.1519/ JSC.0b013e3181b3e141; PMid: 19704378

Strudwick, A., Reilly, T., \& Doran, D. (2002). Anthropometric and fitness profiles of elite players in two football codes. Journal of Sports Medicine and Physical Fitness, 42(2), 239-242.

Taskin, H. (2008) Evaluating sprinting ability, density of acceleration, and speed dribbling ability of professional soccer players with respect to their positions. The Journal of Strength and Conditioning Research, 22(5), 1481-1486. doi: 10.1519/JSC.0b013e3181fd90; PMid: 18714240

Weineck, J. (2007). Optimales Training: leistungsphysiologische Trainingslebre unter besonderer Berücksicbtigung des Kinder- und Jugendtrainings [Optimal training: Exercise physiology, training theory with special emphasis on children and 
youth training]. Balingen, DE: SpittaVerlag GmbH \& Co. KG.

Wisløff, U., Castanga, C., Helgerud, J., Jones, R., \& Hoff, J. (2004). Strong correlation of maximal squat strength with sprint performance and vertical jump height in elite soccer players.British Journal of Sports Medicine, 38, 285-288. doi: 10.1136/bjsm.2002.002071; PMCid:

PMC1724821
Wisløff, U., Helgerud, J., \& Hoff, J (1998). Strenght and endurance of elite soccer players. Medicine and scinece in sports and exercise, 30(3), 462-467. doi: 10.1097/00005768-199803000-00019

Wong, D. P., \& Wong, S. H. S. (2009). Physiological profile of Asian elite youth soccer players.Journal of Strength and Conditioning research, 23, 13831390. doi: 10.1519/JSC.0b013e3181a4f074;

PMid: 19620928

Received: Sepetmber 19, 2013

Revision received: December 9, 2013

Accepted: December 22, 2013

Correspondence to: Pavol Pivovarniček, PhD

Faculty of Humanities MatejBel University Tajovského 40 97401 BanskáBystrica Slovakia

Phone: 00421484467530

E-mail: pavol.pivovarnicek@umb.sk 